\title{
SIGNIFICANCE OF INTERVENTIONAL RADIOLOGY IN LIVER TRANSPLANTATION
}

\author{
VITORIO PERIĆ ${ }^{1}$, HELGA SERTIĆ MILIĆ ${ }^{,}$, TOMICA BRATIĆ ${ }^{1}$, MIRTA ZEKAN VUČETIĆ ${ }^{1}$, \\ NIKOLA IVAN LEDER ${ }^{1}$, THOMAS FERENC ${ }^{1}$ and VINKO VIDJAK ${ }^{1,2}$ \\ ${ }^{1}$ Department of Diagnostic and Interventional Radiology, Clinical Hospital Merkur, Zagreb, Croatia; \\ ${ }^{2}$ School of Medicine, University of Zagreb, Zagreb, Croatia
}

\section{Summary}

Liver transplantation is a method that allows treating of various liver pathological conditions. Interventional radiology (IR) focuses on oncology patients, primarily those with hepatocellular carcinoma. The importance of interventional radiology techniques is in preventing the progression of current liver disease in those patients awaiting liver transplantation and downstaging in patients with unresectable liver tumors to the stage where transplantation is possible.

Chemoembolization (TACE), i.e., conventional transarterial chemoembolization (cTACE) or with drug particles (DEBTACE), radioembolization (SIRT), BLAND embolization, radiofrequency ablation (RFA), and microwave ablation (MWA) are the most widely used IR methods in the treatment of liver cancer. cTACE is a form of TACE in which a high dose of cytostatic is injected into the feeding vessel and the tumor's microenvironment, and then the blood vessels that feed the tumor are embolized. DEB-TACE is a form of TACE in which a cytostatic bind to bead particles that gradually release the drug within the liver tumor itself after injection. BLAND embolization is an IR method of TACE based on ischemia of tumor tissue by IR procedure of embolization and occlusion of the feeding vessel that supplies the tumor, without the use of chemotherapeutics. Transarterial radioembolization is a method that uses endovascular techniques to bring radiospheres containing a radioactive substance near the tumor. Radiofrequency ablation (RFA) is an IR percutaneous method of treatment in which an RF needle inserted into a liver tumor releases heat that causes coagulation necrosis of tumor cells. MWA is an IR percutaneous method of treatment that uses molecules with an internal dipole moment, which move kinetic energy and then heat inside the tumor via a percutaneously inserted MWA needle into the tumor.

KEYWORDS: first-line treatment, metastatic urothelial bladder cancer, maintenance immunotherapy

\section{INTRODUCTION}

Interventional radiology (IR) is based on innovative, less invasive procedures that reduce the incidence of complications and mortality in relation to previously used, more invasive surgical procedures. IR also provides greater opportunities in disease diagnosis in the form of cytological punctures and histological biopsies. The basic

Corresponding author: Vitorio Perić, Department of Diagnostic and Interventional Radiology, Clinical Hospital Merkur, Zajčeva ul. 19, 10000 Zagreb, Croatia. e-mail: vitorioperic@gmail.com principle of IR is intervention through needles or a catheter inserted by the percutaneous puncture. Procedures are performed under X-ray fluoroscopy, ultrasound, or CT guidance. IR treatments of liver pathology include chemoembolization (TACE) methods (cTACE, DEB-TACE, radioembolization and BLAND-embolization) and ablation (radiofrequency-RFA and microwave-MWA)(1). Liver cirrhosis is the most common indication for liver transplantation, an irreversible pathological condition usually caused by excessive alcohol consumption, biliary cirrhosis, or sclerosing cholangitis. IR methods allow for better outcomes in hepatocellular cancer (HCC) treatments. 


\section{DIAGNOSTIC DEVICES USED IN THE DIAGNOSIS OF LIVER DISEASE}

Radiological procedures used in diagnosing and treating liver pathology include ultrasound (US), computed tomography and multislice computed tomography (CT/MSCT), magnetic resonance imaging (MRI), color Doppler (CD), and digital subtraction angiography (DSA).

Most procedures are performed under US guidance because of its simplicity and availability without known complications and contraindication. Different invasive diagnostic and therapeutic methods performed under US guidance include puncture and biopsy of liver lesions and therapeutic radiofrequency ablation of liver metastases.

The CD show changes in portal blood flow, which is extremely useful for post-transplant check-ups and to differentiate individual liver tumors based on measured differences in vascularization(2).

CT/MSCT are methods that are complementary to US and are used to analyze the liver

parenchyma. After intravenous contrast administration, MSCT provides multiphase CT angiography (CTA) with detailed imaging of visceral arteries, portal system, and hepatic veins.

Table 1.

Child-Pugh score correlation with disease prognosis.

\begin{tabular}{|l|l|l|l|}
\hline Group & A & B & C \\
\hline $\begin{array}{l}\text { Child-Pugh } \\
\text { score }\end{array}$ & $\begin{array}{l}\text { Less than } \\
\text { or equal to 6 }\end{array}$ & 7-9 points & $10-15$ points \\
\hline Prognosis & Good & Variable & Poor \\
\hline
\end{tabular}

In comparison to the US and CT/MSCT, MRI has an advantage in diagnosing small lesions surrounded by edema. Moreover, MRI also supplies additional information about parenchymal diseases. MRI angiography using paramagnetic contrast provides detailed imaging of blood vessels. Disadvantages of MRI are longevity imaging that results in artifacts caused by patient movement and the inability to display small calcifications(3).

DSA allows imaging of the blood vessels of the liver but also provides the possibility for transjugular liver biopsy. Today, the role of DSA is crucial in the implementation of TACE and other IR treatment methods(4).

\section{DIAGNOSTIC ALGORITHMS IN THE TREATMENT OF HCC}

Diagnostic algorithms used for diagnosing liver disease are based on radiological findings, clinical symptoms, and the psychophysical condition of the patient. The purpose is to present the liver disease objectively and correctly by categorizing the condition according to the perceived changes inpatient and comparing it with the default criteria. Therefore, it presents the basis for further treatment and monitoring the effect of treatment. Prognostic clinical parameters used in evaluating liver disease include liver function (defined by the Child-Pugh classification), tumor status, tumor size, number of tumors, vascular invasion, and extrahepatic enlargement(5).

The BCLC (Barcelona Clinic for Liver Cancer) classification has the highest prognostic value

Table 2

BCLC score correlation with possible treatment.

\begin{tabular}{|l|l|l|l|l|}
\hline BCLC score & 0 and A & B & C & D \\
\hline Findings & $\begin{array}{l}\text { 1-3 tumors, less than } 3 \mathrm{~cm} \text { in diameter. } \\
\text { No extrahepatic enlargement and } \\
\text { vascular invasion. } \\
\text { Liver function is preserved. } \\
\text { ECOG status 0. }\end{array}$ & $\begin{array}{l}\text { Multifocal tumor without } \\
\text { vascular invasion and } \\
\text { extrahepatic enlargement. } \\
\text { ECOG status 0. }\end{array}$ & $\begin{array}{l}\text { One or more positive } \\
\text { parameters including } \\
\text { extrahepatic enlargement, } \\
\text { vascular invasion and } \\
\text { ECOG status 1-2. }\end{array}$ & $\begin{array}{l}\text { Poor liver } \\
\text { function and } \\
\text { ECOG status } \\
\text { greater than 2. }\end{array}$ \\
\hline Treatment & Ablation, resection and transplantation. & $\begin{array}{l}\text { If liver function is preserved, } \\
\text { chemoembolization }\end{array}$ & $\begin{array}{l}\text { Systemic therapy } \\
\text { (sorafenib and } \\
\text { regorafenib). }\end{array}$ & $\begin{array}{l}\text { Supportive } \\
\text { therapy. }\end{array}$ \\
\hline
\end{tabular}

Table 3.

RECIST category correspondence to treatment efficacy.

\begin{tabular}{|l|l|l|l|}
\hline RECIST category & 1 & 2 & 3 \\
\hline Treatment efficacy & Condition improved & Condition remained the same & Worsening of the conditions \\
\hline
\end{tabular}



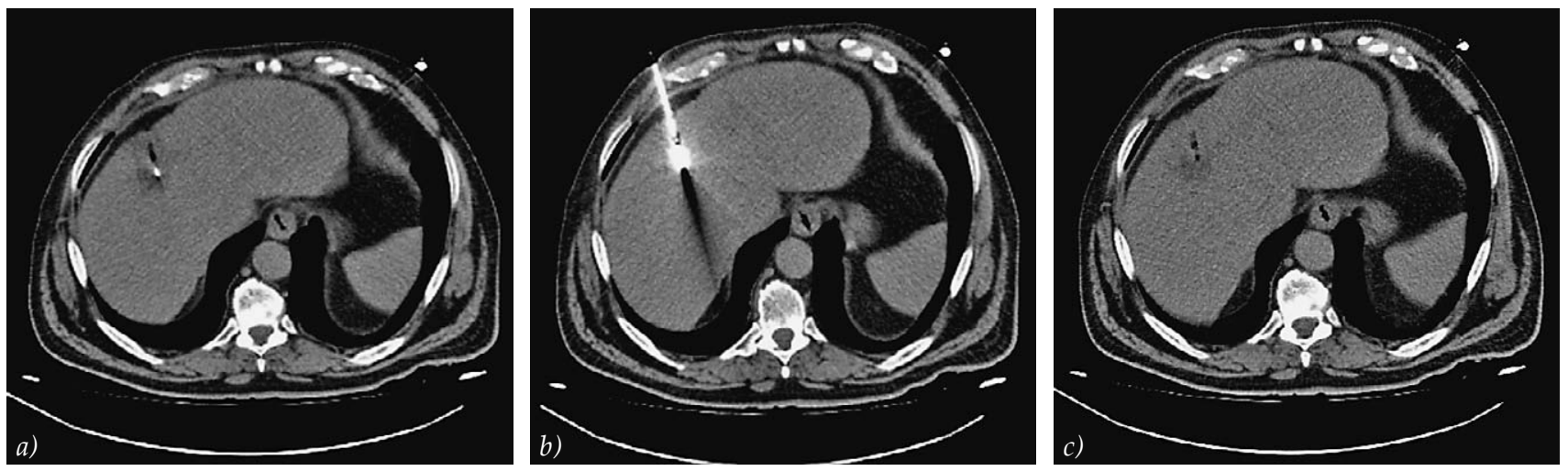

Fig 1. Axial MSCT demonstrates: a) the position of MWA needle in the initial stage of application, $b$ ) the position of MWA needle in ablation zone, c) appearance of liver lesion after MWA procedure (MSCT - multislice computed tomography, MWA - microwave ablation)

Source: Department of diagnostic and interventional radiology, Clinical Hospital Merkur, Zagreb, Croatia

in HCC classification and treatment modalities. It includes the ECOG status of the patient, hepatic function (based on Child-Pugh score), and radiologically determined cancer spread(6).

ECOG status of patients classifies patients into five categories, from fully preserved ability to perform daily activities to a dead patient(7).

The Child-Pugh classification is used to assess liver function and is based on the presence of ascites, portal encephalopathy, elevated blood bilirubin and albumin levels, and prothrombin time. The sum of the scores of these categories classifies patients into three groups (table 1).

Based on BCLC classification, the patients suffering from HCC are stratified in 5 groups (table 2).

The Milan criteria are the most commonly used classification in transplant medicine. The patient meets the liver transplantation criteria only if suffering from one tumor smaller than 5 centimeters or no more than three tumors smaller than 3 centimeters and if there is no extrahepatic cancer spread and vascular invasion(8).

The RECIST criteria (The Response Evaluation Criteria in Solid Tumors) classify patients into 3 categories based on treatment efficacy(9) (table 3).

Compared to standard RECIST criteria, mRECIST (modified RECIST) criteria provide a more detailed tumor progression assessment. Also, mRECIST is used in evaluating the effectiveness of novel treatments and combined therapies(10).

\section{TREATMENT OF LIVER DISEASE}

Conservative treatment of liver disease is most often performed in patients suffering from disseminated tumor disease. The symptoms associated with cirrhosis are treated with beta-blockers, diuretics, and antibiotics. Antiviral therapy is prescribed if cirrhosis is caused by hepatitis.

Sorafenib is used as systemic therapy for patients with advanced $\operatorname{HCC}(11,12)$.

Portal vein embolization (PVE) is the intervention based on redirecting portal blood in segments of the future liver remnant. Such an approach results in hypertrophy of remnant liver volume. Compared to partial liver resection, PVE reduces postoperative morbidity and potential liver dysfunction $(13,14)$.

Partial liver resection is often used in curative and palliative care. It is based on the high ability of liver regeneration, which enables resection of larger parts of the pathologically altered liver with a highly favorable outcome(15).

Orthotopic liver transplantation (OLT) is a surgical procedure in which pathologically altered host liver is replaced with donor liver.

Although the gold standard for the treatment of liver tumors presents liver transplantation together with partial resection techniques, only a small number of patients meet the necessary criteria(16).

IR treatments include a set of ablation and chemoembolization methods that enable the de- 

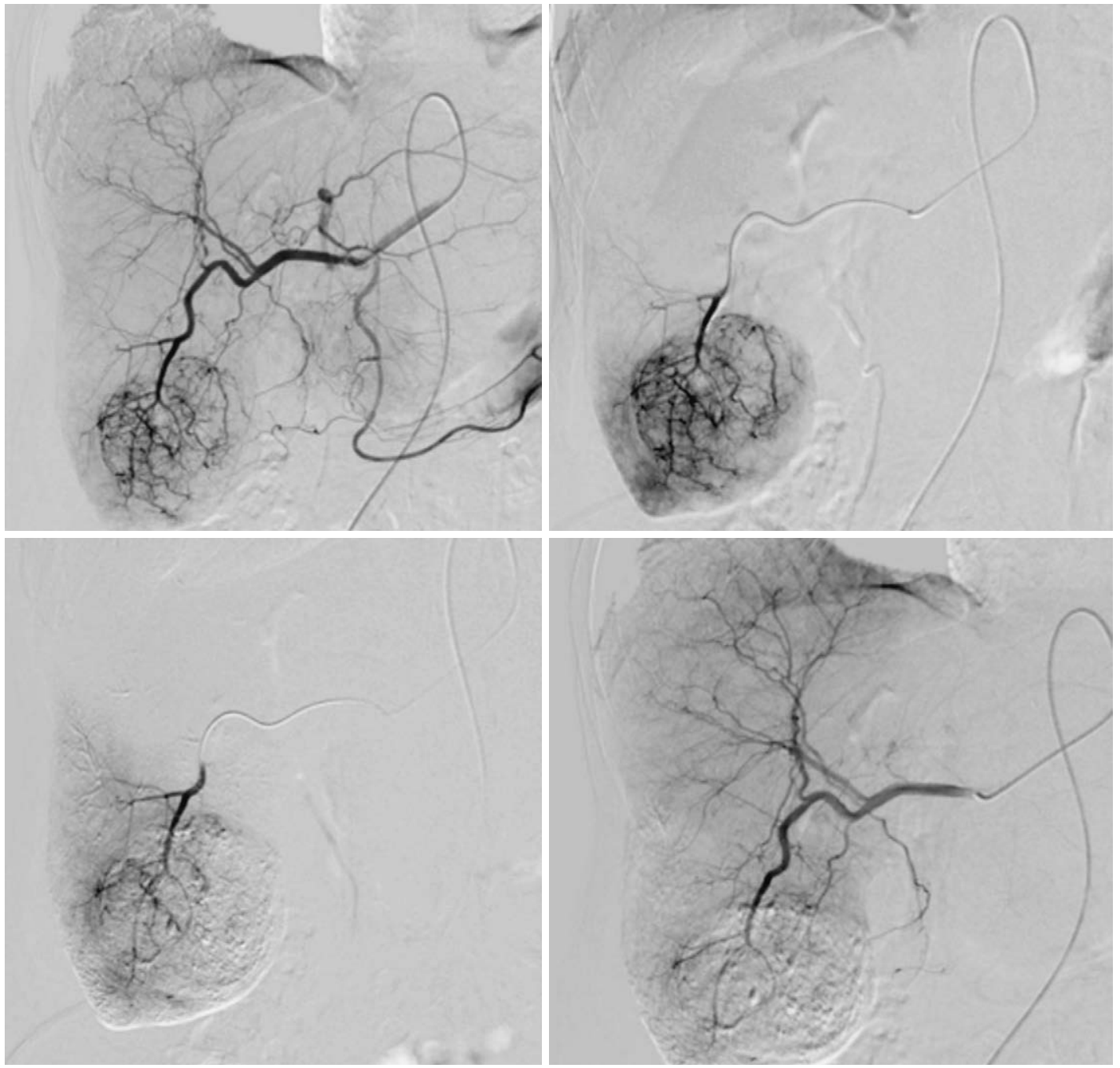

Fig 2. DSA demonstrates: a) selective angiography of HA with a hypervascular lesion (HCC) in VI segment, b) subselective presentation of a segmental artery with a hypervascular lesion (HCC), c) subselective presentation of VI segmental artery after CTACE, d) selective HA angiography condition after cTACE procedure (DSA - digital subtraction angiography, HCC - hepatocellular cancer, HA - hepatic artery, cTACE - conventional transarterial chemoembolization)

Source: Department of diagnostic and interventional radiology, Clinical Hospital Merkur, Zagreb, Croatia

struction of tumor cells without surgical resection of the tumor.

Contraindications associated with IR methods include acute hepatic decompensation, severe iodinated contrast allergies, portal vein thrombosis, severe coagulopathy, acute renal failure, active inflammation in any organ, heart dysfunction, high intrahepatic tumor burden or extrahepatic tumor burden(17).

Ablation methods are particularly useful in patients with advanced tumor disease who do not currently meet the resection and/or transplantation criteria. The most common indications for ablation include HCC and colorectal cancer metastases. In recent times, ablation is increasingly used to treat benign hepatic hemangiomas and metastases from other sites, including breast, kidney, and various neuroendocrine tumors. The most commonly used ablation methods include radiofrequency (RFA) and microwave ablation (MWA)(18).

RFA is mostly used in the treatment of inoperable liver metastases. This method is based on 
Table 4.

Different types of TACE.

\begin{tabular}{|l|l|l|l|l|}
\hline & cTACE & DEB-TACE & Radioembolization & BLAND embolization \\
\hline Size of microsphere & $30-60$ micrometer & $100-300$ micrometer & $20-60$ micrometer & $40-100$ micrometer \\
\hline Ethiodized oil & Lipiodol & $/$ & $/$ & $\begin{array}{l}\text { N-butyl-cyanoacrilate } \\
\text { Lipiodol }\end{array}$ \\
\hline $\begin{array}{l}\text { Chemotherapeutic/ } \\
\text { radioactive matter }\end{array}$ & $\begin{array}{l}\text { Epirubicin } \\
\text { Miriplatine }\end{array}$ & $\begin{array}{l}\text { Doxorubicin } \\
\text { Irinotecan }\end{array}$ & $\begin{array}{l}\text { Radioisotope Yttrium-90 } \\
\left({ }^{90 Y}\right)\end{array}$ & $/$ \\
\hline Mechanism of action & $\begin{array}{l}\text { Local application of } \\
\text { chemotherapeutic } \\
\text { emulsified in Lipiodol }\end{array}$ & $\begin{array}{l}\text { Drug-eluting beads } \\
\text { containing } \\
\text { chemotherapeutic }\end{array}$ & $\begin{array}{l}\text { Radiation that causes the } \\
\text { formation of free oxygen } \\
\text { radicals }\end{array}$ & $\begin{array}{l}\text { Embolization of cancer } \\
\text { arteries }\end{array}$ \\
\hline
\end{tabular}

Table 5.

Studies establishing benefit of different TACE techniques.

\begin{tabular}{|c|c|}
\hline TACE & Studies establishing benefit of procedure \\
\hline cTACE & $\begin{array}{l}\text { 1) Cohort study, } 8510 \text { patients, median of one-year survival of } 84 \% \text {, three-year } 47 \% \text { and five-year } 26 \%(22) \text {. } \\
\text { 2) Cohort study, } 4966 \text { patients, study excluded patients with vascular invasion, extrahepatic metastases and } \\
\text { prior treatment. Medial survival } 3.3 \text { years (23). }\end{array}$ \\
\hline DEB-TACE & $\begin{array}{l}\text { 1) } 27 \text { patient series, response rate } 75 \% \text { by CT at } 6 \text { months. One and } 2 \text {-year survival rates were } 92.5 \% \\
\text { and } 88.9 \%(24) \text {. } \\
\text { 2) Cohort study, } 104 \text { patients. Median survival of } 48 \text { months (25). }\end{array}$ \\
\hline Radioembolization & $\begin{array}{l}\text { 1) } 291 \text { patient, } 17.2 \text { months survival (Child-Pugh A) and } 7.7 \text { months survival (Child-Pugh B) (26). } \\
\text { 2) } 108 \text { patients, } 16.4 \text { months survival (27). }\end{array}$ \\
\hline BLAND embolization & $\begin{array}{l}\text { 1) } 80 \text { patients, two groups treated with different embolic agents (microspheres (ME) and polyvinyl alcohol } \\
\text { (PVA)), median survival was } 39 \text { months in both groups (28) }\end{array}$ \\
\hline
\end{tabular}

introducing a radiofrequency electrode in the shape of a needle into the target organ. The highfrequency generator generates the heat needed for tissue necrosis. The success of RFA is enhanced by previous percutaneous embolization of blood vessels near cancer. The greatest efficiency of RFA treatment is achieved in those patients with primary tumor size up to 3 centimeters(19).

MWA is a method based on the constant movement of molecules with an internal dipole moment in a variable field. Compared to RFA, MWA does not require prior embolization of blood vessels. This method has been particularly successful in 'downstaging' in patients suffering from disseminated tumor disease(20) (Fig 1).

The success of the ablation method is evaluated by determining the minimum ablation margin (MAM) by contrast MSCT immediately after the procedure and is compared with the MSCT finding 3 to 6 months later. Possible local tumor progression (LTP) is monitored by comparison of the findings.

Transarterial chemoembolization (TACE) is a technique based on the difference in blood supply to a healthy liver parenchyma and tumor (Fig 2).
Unlike healthy liver parenchyma, which receives about $70 \%$ of blood supply through the portal vein, a tumor receives most of its blood through the hepatic artery. The chemotherapeutic agent is mixed with oil contrast particles (Lipiodol) which retain the chemotherapeutic in tumor arterioles and lead to slow and continuous drug release(21).

TACE includes conventional TACE (cTACE), drug-eluting beads TACE (DEB-TACE), radioembolization and BLAND embolization (table 4).

Various studies have been conducted to determine the effectiveness of individual TACE methods (table 5)

\section{DISCUSSION}

Although partial resection and transplantation represent the gold standard in the treatment of liver cancer, only $30 \%$ of patients present at a sufficiently early stage where they meet the necessary transplantation criteria(16). Therefore, IR methods serve as an excellent addition to standard surgical procedures. Due to the possibility of avoiding general anesthesia and its minimal invasiveness, IR methods are available for a more sig- 
nificant number of patients. Of particular benefit is the option of 'downstaging' advanced tumor disease and classifying the patient into transplant criteria. Numerous studies have been conducted to evaluate the effectiveness and risk of individual IR methods and a combination of different IR methods in the treatment of liver cancer.

Comparing the combination of cTACE/RFA methods with the independent use of the cTACE method, better outcomes in terms of less local tumor progression (LTP) and longer time to progression (TTP) were observed when using combination cTACE/RFA (29).

According to Si et al., MWA followed by TACE provides a safe and effective method in treating large $\mathrm{HCC}(30)$. Moreover, different studies based on comparing CTACE and DEB-TACE show slightly better outcomes after using the DEB-TACE method in terms of lower peak blood concentrations of cytostatic. This may contribute to a weaker systemic response(31).

To conclude, IR methods provide great alternatives and addition to surgical procedures.

\section{REFERENCES}

1. Murata S, Niggemann P, Lee EW, Hol PK. Diagnostic and interventional radiology for liver diseases. Biomed Res Int. 2015;2015:147583. doi:10.1155/2015/147583

2. Shi H, Wang $Y$, Wang H, Zhao H, Xv N, Liu F, Peng X. Use of three-dimensional color power doppler in imaging of liver cancer. J Biol Regul Homeost Agents. 2016 Jul-Sep;30(3):801-806.

3. Siegelman ES, Chauhan A. MR characterization of focal liver lesions: pearls and pitfalls. Magn Reson Imaging Clin N Am. 2014 Aug;22(3):295-313. doi: 10.1016/j. mric.2014.04.005.

4. Liu A, Xu W, Xu H, Wang Y, Zhao HL, Sha JC, Gu YM. Application of three-dimensional digital subtraction angiography on hepatic artery chemoembolization. Zhonghua Gan Zang Bing Za Zhi. 2018 Jun 20;26(6): 436-440. doi: 10.3760/cma.j.issn.1007-3418.2018.06.009.

5. Abbott WJ, Thomson A, Steadman C, Gatton ML, Bothwell C, Kerlin P, et al. Child-Pugh class, nutritional indicators and early liver transplant outcomes. Hepatogastroenterology. 2001 May-Jun;48(39):823-7.

6. Llovet JM, Brú C, Bruix J. Prognosis of hepatocellular carcinoma: the BCLC staging classification. Semin Liver Dis. 1999;19(3):329-38. doi: 10.1055/s-2007-1007122.

7. Azam F, Latif MF, Farooq A, et al. Performance Status Assessment by Using ECOG (Eastern Cooperative Oncology Group) Score for Cancer Patients by Oncology Healthcare Professionals. Case Rep Oncol. 2019; 12(3):728-736. Published 2019 Sep 25. doi:10.1159/000 503095
8. Gunsar F. Liver Transplantation for Hepatocellular Carcinoma Beyond the Milan Criteria. Exp Clin Transplant. 2017;15(Suppl 2):59-64. doi:10.6002/ect.TOND 16.L16

9. Schwartz LH, Litière S, de Vries E, Ford R, Gwyther S, Mandrekar S, etval. RECIST 1.1-Update and clarification: From the RECIST committee. Eur J Cancer. 2016; 62:132-7. doi:10.1016/j.ejca.2016.03.081.

10. Llovet JM, Lencioni R. mRECIST for HCC: Performance and novel refinements. J Hepatol. 2020 Feb;72 (2):288-306. doi: 10.1016/j.jhep.2019.09.026.

11. Llovet JM, Ricci S, Mazzaferro V, et al. Sorafenib in advanced hepatocellular carcinoma. N Engl J Med. 2008; 359(4):378-390. doi:10.1056/NEJMoa0708857

12. Vagefi PA, Hirose R. Downstaging of hepatocellular carcinoma prior to liver transplant: is there a role for adjuvant sorafenib in locoregional therapy. J Gastrointest Cancer. 2010;41(4):217-220. doi:10.1007/s12029010-9163-y

13. May BJ, Madoff DC. Portal vein embolization: rationale, technique, and current application. Semin InterventRadiol.2012;29(2):81-89.doi:10.1055/s-0032-1312568

14. Rauchfuss F, Scheuerlein H, Lopatta E, Dittmar Y, Schüle S, Settmacher U. Pfortaderembolisation zur Konditionierung erweiterter Leberresektionen - aktueller Stand und Ausblick [Portal vein embolisation prior to extended liver resection - current and future aspects]. Zentralbl Chir. 2013 Aug;138(4):442-8. German. doi: 10.1055/s-0032-1328350.

15. Akoad ME, Pomfret EA. Surgical resection and liver transplantation for hepatocellular carcinoma. Clin Liver Dis. 2015 May;19(2):381-99. doi: 10.1016/j.cld. 2015.01.007.

16. Belghiti J, Kianmanesh R. Surgical treatment of hepatocellular carcinoma. HPB (Oxford). 2005;7(1):42-49. doi:10.1080/13651820410024067

17. Liang P, Yu J, Lu MD, et al. Practice guidelines for ultrasound-guided percutaneous microwave ablation for hepatic malignancy. World J Gastroenterol. 2013; 19(33):5430-5438. doi:10.3748/wjg.v19.i33.5430

18. Tan W, Deng Q, Lin S, Wang Y, Xu G. Comparison of microwave ablation and radiofrequency ablation for hepatocellular carcinoma: a systematic review and meta-analysis. Int J Hyperthermia. 2019;36(1):264-272. doi: 10.1080/02656736.2018.1562571.

19. Zheng L, Zhang CH, Lin JY, Song CL, Qi XL, Luo M. Comparative Effectiveness of Radiofrequency Ablation vs. Surgical Resection for Patients With Solitary Hepatocellular Carcinoma Smaller Than $5 \mathrm{~cm}$. Front Oncol. 2020 Mar 31;10:399. doi: 10.3389/fonc.2020.00399.

20. Shi F, Lian S, Mai Q, et al. Microwave ablation after downstaging of hepatocellular carcinoma: outcome was similar to tumor within Milan criteria. Eur Radiol. 2020;30(5):2454-2462. doi:10.1007/s00330-019-06604-y

21. Raoul JL, Forner A, Bolondi L, Cheung TT, Kloeckner $\mathrm{R}$, de Baere T. Updated use of TACE for hepatocellular carcinoma treatment: How and when to use it based 
on clinical evidence. Cancer Treat Rev. 2019 Jan;72:2836. doi: 10.1016/j.ctrv.2018.11.002.

22. Takayasu K, Arii S, Ikai I, et al. Prospective cohort study of transarterial chemoembolization for unresectable hepatocellular carcinoma in 8510 patients. Gastroenterology. 2006;131:461-9.

23. Takayasu K, Arii S, Kudo M, et al. Superselective transarterial chemoembolization for hepatocellular carcinoma. Validation of treatment algorithm proposed by Japanese guidelines. J Hepatol. 2012;56:886-92

24. Varela M, Real MI, Burrel M, et al. Chemoembolization of hepatocellular carcinoma with drug eluting beads: efficacy and doxorubicin pharmacokinetics. J Hepatol. 2007;46:474-81.

25. Burrel M, Reig M, Forner A, et al. Survival of patients with hepatocellular carcinoma treated by transarterial chemoembolisation (TACE) using Drug Eluting Beads. Implications for clinical practice and trial design. J Hepatol. 2012;56:1330-5

26. Salem R, Lewandowski RJ, Mulcahy MF, et al. Radioembolization for hepatocellular carcinoma using Yttrium-90 microspheres: a comprehensive report of longterm outcomes. Gastroenterology. 2010;138:52-64.

27. Hilgard P, Hamami M, Fouly AE, et al. Radioembolization with yttrium-90 glass microspheres in hepatocellular carcinoma: European experience on safety and long-term survival. Hepatology. 2010;52:1741-9.
28. Armani Scaffaro L, Pinto Kruel CD, Frosi Stella S, Leal Gravina G, Machado Filho G, Borges de Almeida CP, et al. Transarterial embolization for hepatocellular carcinoma: A comparison between nonspherical PVA and microspheres. BioMed Research International. 2015;vol. 2015, Article ID 435120. https://doi.org/ $10.1155 / 2015 / 435120$

29. Lee H, Yoon CJ, Seong NJ, Jeong SH, Kim JW. Comparison of combined therapy using conventional chemoembolization and radiofrequency ablation versus conventional chemoembolization for ultrasound-invisible early-stage hepatocellular carcinoma (Barcelona clinic liver cancer stage 0 or A). Korean J Radiol. 2018;19(6):1130-1139. doi:10.3348/kjr.2018.19.6.1130

30. Si ZM, Wang GZ, Qian S, Qu XD, Yan ZP, Liu R, Wang $\mathrm{JH}$. Combination therapies in the management of large $(\geq 5 \mathrm{~cm})$ hepatocellular carcinoma: microwave ablation Immediately followed by transarterial chemoembolization. J Vasc Interv Radiol. 2016 Oct;27(10): 1577-83. doi: 10.1016/j.jvir.2016.02.014.

31. van Malenstein H, Maleux G, Vandecaveye V, Heye S, Laleman W, van Pelt J, et al. A randomized phase II study of drug-eluting beads versus transarterial chemoembolization for unresectable hepatocellular carcinoma. Onkologie. 2011;34(7):368-76. doi: 10.1159/000 329602.

Sažetak

\title{
ZNAČAJ INTERVENCIJSKE RADIOLOGIJE U TRANSPLANTACIJI JETRE
}

\author{
V. Perić, H. Sertić Milić, T. Bratić, M. Zekan Vučetić, N. I. Leder, T. Ferenc, V. Vidjak
}

Transplantacija jetre je metoda koja omogućuje liječenje brojnih jetrenih patoloških stanja. Intervencijska radiologija (IR) najveći značaj pruža liječenju onkoloških pacijenata, najčešće onima s hepatocelularnim karcinomom. Odlike interventnih radioloških tehnika ogledaju se ponajprije u prevenciji progresije trenutne jetrene bolesti te smanjenju stupnja proširenosti tumorske bolesti. U najčešće korištene IR metode u liječenju jetrenih tumora svrstavaju se transarterijska kemoembolizacija (TACE), tj. konvencionalna transarterijska kemoembolizacija (cTACE) ili TACE česticama koje sadržavaju citostatik (DEB-TACE), radioembolizacija, BLAND embolizacija, radiofrekvencijska ablacija (RFA) te mikrovalna ablacija (MWA). CTACE metoda konvencionalni je oblik TACE metode temeljen na lokalnoj aplikaciji citostatika u mikrookoliš tumora te embolizaciji krvnih žila koje opskrbljuju tumor. DEB-TACE metoda zasniva se na lokalnoj aplikaciji čestica ispunjenih citostatikom koje omogućavaju konstantno otpuštanje lijeka u tumorski mikrookoliš.

BLAND embolizacijom emboliziraju se krvne žile koje opskrbljuju tumor što rezultira tumorskom ishemijom. Transarterijska radioembolizacija metoda je kojom se radiosferama apliciraju radioaktivne supstance u tumorski mikrookoliš. RFA tehnika zasnovana je na aplikaciji toplinske energije kroz radiofrekvencijsku iglu uvedenu u jetreni tumor što rezultira koagulacijskom nekrozom tumora.

MWA je metoda zasnovana na perkutanoj aplikaciji molekula sa unutarnjim dipolom koje u kombinaciji sa vanjskim promjenjivim poljem uzrokuju produkciju topline što rezultira nekrozom tumora.

KLJUČNE RIJEČI: transplantacija, kemoembolizacija, radioembolizacija, ablacija 